\title{
Microstructural properties and antibacterial activity of Ce doped NiO through chemical method
}

\author{
M. Abdur Rahman ${ }^{1} \cdot$ R. Radhakrishnan ${ }^{2}$
}

(C) Springer Nature Switzerland AG 2019

\begin{abstract}
The nickel oxide and different concentration of Cerium ions $(0.01 \mathrm{M}, 0.02 \mathrm{M}$ and $0.03 \mathrm{M})$ doped $\mathrm{NiO}$ nanoparticles (NPs) were synthesized by chemical method. The XRD spectra exhibited the cubic structure of NiO. The average crystalline sizes were observed as $43 \mathrm{~nm}, 36 \mathrm{~nm}, 29 \mathrm{~nm}$ and $23 \mathrm{~nm}$ in NiO and Ce doped NiO NPs, respectively. The Ni (2p), O (1s) and $\mathrm{Ce}(3 \mathrm{~d})$ oxidation states were confirmed by XPS spectra. The FESEM image and TEM image showed the flowers with spherical nanostructure in undoped and doped NiO NPs. The Chemical compositions were identified by EDAX spectra. Metal-oxide (Ni-O) functional groups were found at $439,435,445$ and $446 \mathrm{~cm}^{-1}$ in undoped and doped samples respectively. The optical studies were carried out using UV-Vis spectra and PL studies. Magnetization values were enhanced in Ce doped NiO NPs as compared to NiO NPs. Antibacterial activities were done by various human pathogens with using $\mathrm{NiO}$ and $\mathrm{Ce}$ doped NiO NPs.
\end{abstract}

Keywords NiO NPs · Ce doped NiO NPs · XRD · PL · Oxygen vacancies · VSM · Antibacterial activity

\section{Introduction}

Rare earth (RE) 3d ion doped with $\mathrm{NiO}$ has been intensively studied in the past decade, to obtain better optical and magnetic properties [1]. RE atoms are possessing the special $4 \mathrm{f}$ shells. RE atoms are the excellent candidates for the luminescence centers of doped materials due to the transition of intra $-4 f$ or $4 f-5 d$ narrow emission line. The transition plays the important roles in the absorption of RE atoms in the UV range. An energy transfer process from the excited semiconductor host to doping lanthanide atoms, promoted the doped NPs to circumvent absorption of optical centers with extraordinary improvement of luminescent properties [2,3]. Cerium as one element of Lanthanide doped semiconductors has been used in the focus of numerous unique potential applications like optical properties and biomedical applications [4-8]. The NiO NPs are $p$-type semiconductors and have stable wide band gap (3.4-4.0 eV) [9]. The NiO NPs are one of the promising metal oxides for various potential applications like alkaline batteries, gas sensors, electrochemical capacitors, smart windows, biomedicine, drug delivery, and magnetic bar codes [10-15].

The mechanism of antibacterial actions of the material states were productions of reactive oxygen species (ROS) [16] on the surface of these NPs in the light causes oxidative stress in bacterial cells eventually, leading to death of the cells. Reactive oxygen species contain the most reactive hydroxyl radical $(\mathrm{OH})$, the less toxic superoxide anion radical $\left(\mathrm{O}_{2}^{-}\right)$and hydrogen peroxide with a weaker oxidizer $\left(\mathrm{H}_{2} \mathrm{O}_{2}\right)$. This can damage Deoxyribo nucleic acid (DNA), cell membranes, etc., which lead to cell death [17]. The attachment of the NPs to the bacteria has also been demonstrated. This is attributed to the electrostatic attraction between the negatively charged bacteria and the positively charged NPs. Such a contact may not only

$\triangle$ M. Abdur Rahman, abdur84@gmail.com | ${ }^{1} \mathrm{PG}$ and Research Department of Physics, Sudharsan College of Arts and Science, Pudukkottai, Tamilnadu 622 104, India. ${ }^{2}$ PG and Research Department of Physics, Jamal Mohamed College (Autonomous), Tiruchirapalli, Tamilnadu 620 020, India.

SN Applied Sciences (2019) 1:221 | https://doi.org/10.1007/s42452-019-0232-y 
inhibit bacterial growth, but also the generated reactive oxygen species may kill the cell [18]. It suggests that both $\mathrm{NiO}$ NPs and $\mathrm{Ni}^{2+}$ are toxic, but have different modes of actions which take place in the antibacterial cell death.

In the present investigations, $\mathrm{NiO}(\mathrm{A} 1)$, [cerium] $\mathrm{Ce}^{3+}$ ions $(0.01 \mathrm{M}(\mathrm{A} 2), 0.02 \mathrm{M}(\mathrm{A} 3)$ and $0.03 \mathrm{M}(\mathrm{A} 4))$ doped $\mathrm{NiO}$ samples are synthesized by chemical method. The Synthesized samples are studied in structural, optical, magnetic and antibacterial properties of $A 1, A 2, A 3$ and $A 4$ samples and examined.

\section{Materials and method}

Nickel (II) nitrate hexahydrate (AR), cerium (III) nitrate hexahydrate (AR) and $\mathrm{NaOH}(A R)$ were used as precursor materials for the synthesis of $\mathrm{Ni}_{1-x} \mathrm{Ce}_{x} \mathrm{O}$ (where $\mathrm{x}=0.0,0.01$, 0.02 and 0.03 ) series.

The experimental procedure for the preparation of $\mathrm{NiO}$ NPs (A1) sample has been reported in our previous paper [1]. In the case of $\mathrm{Ce}$ doped $\mathrm{NiO}$ samples, the synthesis of $\mathrm{Ni}_{1-\mathrm{x}} \mathrm{Ce}_{\mathrm{x}} \mathrm{O}(\mathrm{x}=0.01 \mathrm{M}(\mathrm{A} 2), 0.02 \mathrm{M}(\mathrm{A} 3)$ and $0.03 \mathrm{M}(\mathrm{A} 4))$ of cerium nitrate salt solution was mixed with Nickel nitrate solution. $0.8 \mathrm{M}$ of $\mathrm{NaOH}$ solution was added in drops to the homogenous mixed metal solution to form a black precipitate. The black precipitate was washed a number of times with deionized water and ethanol. Further the black precipitate was dried at $120^{\circ} \mathrm{C}$ for $1 \mathrm{~h}$. The obtained Ce doped $\mathrm{NiO}$ samples were annealed at $700^{\circ} \mathrm{C}$ for $5 \mathrm{~h}$ and used for further studies.

The antibacterial activities of the $\mathrm{Ni}_{1-\mathrm{x}} \mathrm{Ce}_{\mathrm{x}} \mathrm{O}$ NPs for $x=0.0(A 1), 0.01 M(A 2), 0.02 M(A 3)$ and $0.03 M(A 4)$ were investigated by the well diffusion method. They have been reported in our previous paper [1].

\subsection{Characterization techniques}

The NiO NPs were characterized by X-ray (XRD) diffractometer (model: X'PERT PRO PANalytical). The diffraction patterns were recorded in the range of $20^{\circ}-80^{\circ}$. The monochromatic wavelength of $1.54 \AA$ was used. The XPS measurements were performed with an XPS (Carl Zeiss) equipment. The spectra were at a pressure using an ultra high vacuum with $\mathrm{Al} \mathrm{Ka}$ excitation at $250 \mathrm{~W}$. The samples were analyzed by Field Emission Scanning Electron (FESEM) Microscopy (Carl Zeiss Ultra 55 FESEM) with EDAX (model: Inca). FT-IR spectra were recorded with using Perkin-Elmer spectrometer. The UV-Vis-NIR spectrum was recorded in the wavelength range $190-1110 \mathrm{~nm}$ using Lambda 35 . The magnetic properties were analyzed by vibrating sample magnetometer (Lakeshore mini VSM 3639).

\section{Results and discussion}

The synthesized $\mathrm{NiO}$ and Ce doped NiO NPs is formed as a cubic structure (Fig. 1), which is well matched with JCPDS card no.: 01-175-0269 (space group Fm3m) without any $\mathrm{CeO}_{2}$ and $\mathrm{Ce}_{2} \mathrm{O}_{3}$. Characteristic peaks of impurities shifted in slight higher angle (20) for A2, A3 and A4 samples as compared to that of $A 1$ samples (Fig. 2).The estimated lattice constant (a), unit cell volume $(\mathrm{V})$ and crystallite size (D) values are (4.182 $\AA, 4.179 \AA, 4.166 \AA$ and $4.162 \AA)$, $\left(73.139 \AA^{3} 72.982 \AA^{3}, 72.303 \AA^{3}\right.$ and $\left.72.095 \AA^{3}\right)$ and $(43 \mathrm{~nm}$, $36 \mathrm{~nm}, 29 \mathrm{~nm}$ and $23 \mathrm{~nm}$ ) for $\mathrm{A} 1, A 2, A 3$ and $A 4$ samples respectively, those changes may be due to the substitution $\mathrm{Ce}^{3+}$ ions into $\mathrm{NiO}$ matrix.

Figure $3 a-c$ shows that $\mathrm{Ni}(2 \mathrm{p}), \mathrm{O}(1 \mathrm{~s})$ and $\mathrm{Ce}(3 \mathrm{~d})$ oxidation state are studied for $\mathrm{Ni}_{0.98} \mathrm{Ce}_{0.02} \mathrm{O}$ NPs using XPS spectra. The Ni $\left(2 \mathrm{p}_{3 / 2}\right)$ and $\mathrm{Ni}\left(2 \mathrm{p}_{1 / 2}\right)$ peaks are $(879.63 \mathrm{eV}$, $871.91 \mathrm{eV}, 866.02 \mathrm{eV}, 860.90 \mathrm{eV}, 855.36 \mathrm{eV}$ and $853.60 \mathrm{eV})$, respectively due to $\mathrm{Ni}^{2+}$ of $\mathrm{NiO}$ and satellite, shakeup structure for A3 NPs [19, 20]. Figure $3 b$ shows Ce $3 d$ state splits into three signals are observed at $(879.34 \mathrm{eV}, 898.42 \mathrm{eV}$ and $906.40 \mathrm{eV}$ ) respectively. The Ce $3 \mathrm{~d}$ state peaks are found at $898.42 \mathrm{eV}$ for $\mathrm{Ce}^{4+} 3 \mathrm{~d}_{5 / 2}$ oxidation states and in

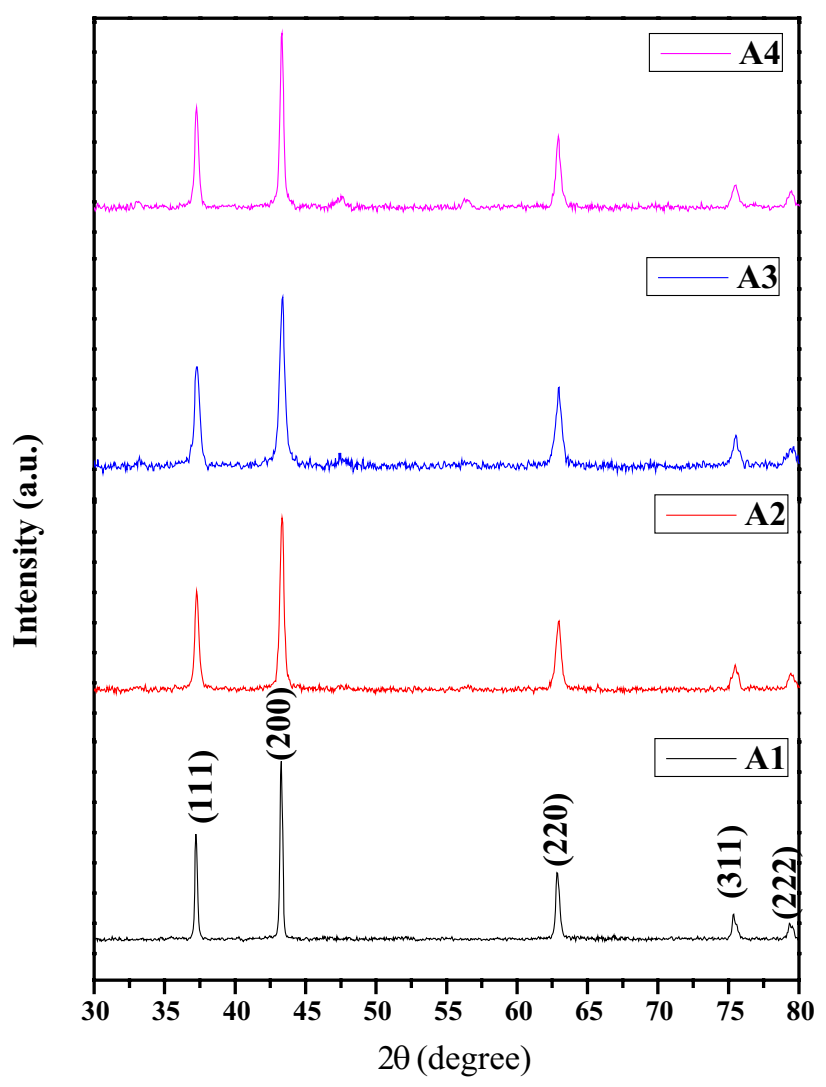

Fig. 1 X-ray diffraction pattern of $\mathrm{Ni}_{1-\mathrm{x}} \mathrm{Ce}_{\mathrm{x}} \mathrm{O}$ nanoparticles for $x=0.0,0.01,0.02$ and 0.03 


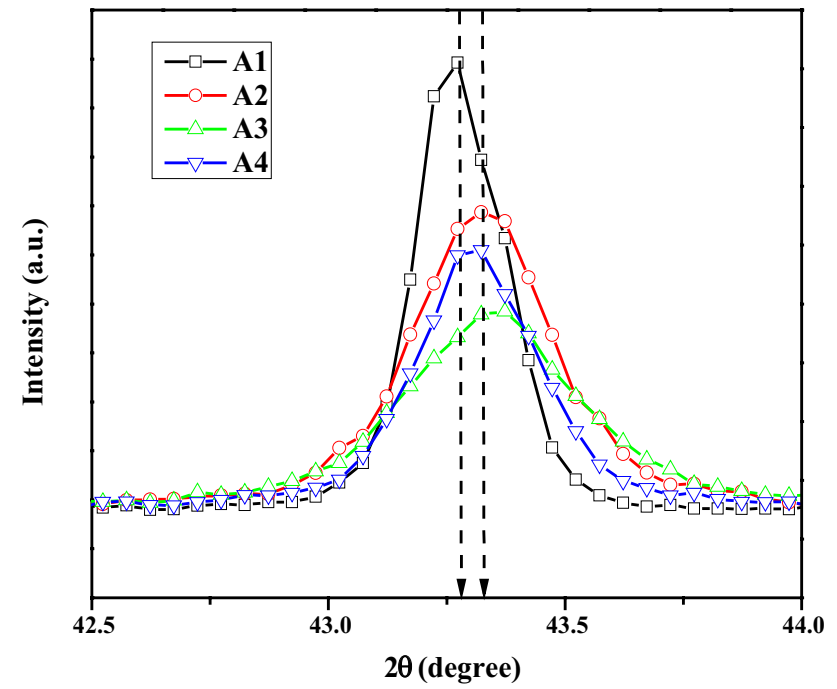

Fig. 2 X-ray powder diffraction patterns of doping-induced peak shift for $\mathrm{NiO}$ and $\mathrm{Ce}$ doped $\mathrm{NiO}$ nanoparticles

addition two satellite $\mathrm{Ce}^{3+}\left(3 \mathrm{~d}_{3 / 2}\right)$ and $\mathrm{Ce}^{3+}\left(3 \mathrm{~d}_{5 / 2}\right)$ states located at $906.40 \mathrm{eV}$ and $879.34 \mathrm{eV}$ for Ce doped $\mathrm{NiO}$ nanoparticles. The $\mathrm{O}(1 \mathrm{~s})$ signals are located at $529.26 \mathrm{eV}$, $530.91 \mathrm{eV}$ and $532.25 \mathrm{eV}$ in Ce doped NiO NPs, this is due to the $\mathrm{O}^{2-}$ in NiO NPs. The atomic percentages of the samples are shown in Table 1.

The FESEM image showed the topography of A1, A2, A3 and A4 samples are shown in Fig. 4a-d. The nanoflower structure with uniform grain boundaries are found in the pure NiO nanoparticles. The Ce doped NiO NPs are exhibited in the spherical structure. Increasing with Ce concentration also decreased with spherical structure in $\mathrm{NiO}$ nanoparticles. These topographical changes are due to $\mathrm{Ce}^{3+}$ ion substitution into $\mathrm{NiO}$ matrix. The average crystal sizes are observed in nanoscale range $25-65 \mathrm{~nm}$ for $\mathrm{NiO}$ and $\mathrm{Ce}$ doped $\mathrm{NiO}$ nanoparticles.

The TEM images showed the morphology of $\mathrm{NiO}$ and $\mathrm{Ni}_{0.97} \mathrm{Ce}_{0.03} \mathrm{O}$ NPs samples are shown in Fig. $5 \mathrm{a}$, b. The Nanoflower and spherical structure for $\mathrm{NiO}$ and $\mathrm{Ni}_{0.97} \mathrm{Ce}_{0.03} \mathrm{O}$ NPs. Figure $6 \mathrm{a}-\mathrm{d}$ showed the elemental composition of $A 1, A 2, A 3$ and $A 4$ samples were identified by the energy dispersive analysis of $x$-ray (EDAX) spectral analysis. In the case of $\mathrm{Ce}$ doped $\mathrm{NiO}$ samples, the $\mathrm{Ce}^{3+}$ ion atomic percentage are observed at $0.60 \%, 1.29 \%$ and $1.67 \%$. In NiO samples, the chemical compositions of $\mathrm{Ni}$ and $\mathrm{O}$ are found to be $55.49 \%$ and $44.51 \%$ (Table 2) respectively. However, in $\mathrm{Ce}$ doped $\mathrm{NiO}$ samples, the Ni percentage decreased whereas the oxygen percentage increased.

A FT-IR spectrum is an easier tool for understanding the functional groups. Figure 7 shows the IR spectra of $\mathrm{NiO}$ and various concentrations of $\mathrm{Ce}$ doped $\mathrm{NiO}$ nanoparticles. The broad $\mathrm{O}-\mathrm{H}$ stretching peaks are observed at $3335,3450,3446$ and $3444 \mathrm{~cm}^{-1}$ for $\mathrm{NiO}$ and Ce doped $\mathrm{NiO}$
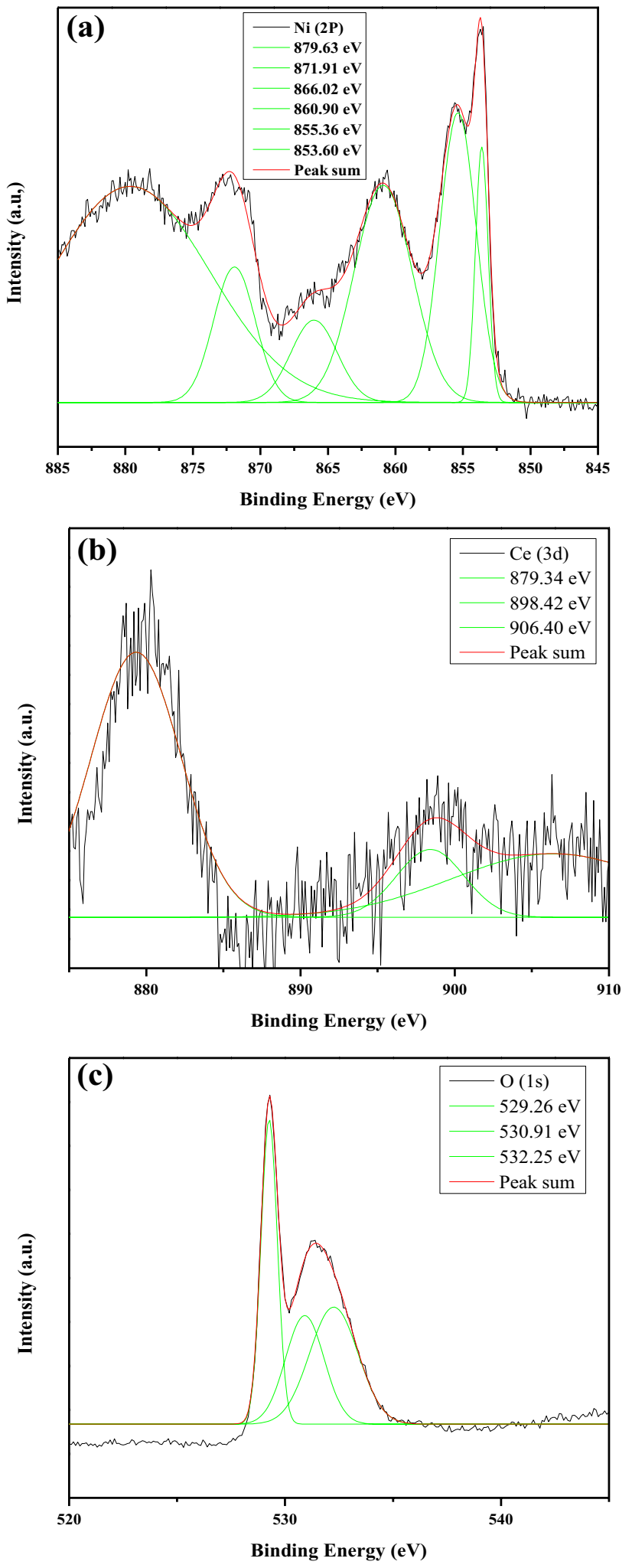

Fig. 3 XPS spectra of a Ni (2p), b O (1s) and c Ce (3d) oxidation state of $\mathrm{Ce}$ doped $\mathrm{NiO}$ nanoparticles 
Table 1 Atomic percentage of Ce doped NiO NPs

\begin{tabular}{lll}
\hline Ni $2 p$ & O 1s & Doping \% \\
\hline Atom. Con \% & Atom. Con \% & Atom. Con \% \\
36.14 & 62.62 & $1.24($ Ce 3d) \\
\hline
\end{tabular}

nanoparticles respectively [21] The week $\mathrm{C}-\mathrm{H}$ symmetric and asymmetric stretching centered at $(2838,2886$ and $\left.2885 \mathrm{~cm}^{-1}\right)$ and $\left(2971,2944\right.$ and $\left.2924 \mathrm{~cm}^{-1}\right)$ were observed in both $\mathrm{NiO}$ nanoparticles. The $\mathrm{O}-\mathrm{H}$ bending vibration observed at 1647, 1641, 1638 and $1635 \mathrm{~cm}^{-1}$ for $\mathrm{NiO}$ and Ce doped NiO NPs respectively, which is attributed to the adsorbed water on the surface of NPs [22]. The absorption peaks observed at $417,415,417$ and $412 \mathrm{~cm}^{-1}$ corresponds to $\mathrm{Ni}-\mathrm{O}$ stretching vibration of $\mathrm{NiO} \mathrm{NPs}$. The absorption peaks observed at 1647, 1636, 1638 and $1636 \mathrm{~cm}^{-1}$ are attributed to the bending mode $\mathrm{H}-\mathrm{O}-\mathrm{H}$ of water molecules for all $\mathrm{NiO}$ nanoparticles. The $\mathrm{Ni}-\mathrm{O}$ stretching bands are observed at 439, 435, 445, and $446 \mathrm{~cm}^{-1}$ in $\mathrm{NiO}$ and $\mathrm{Ce}$ doped NiO nanoparticles [23].

The ultra violet visible (UV-Vis) absorption spectra and the absorption edge peaks are located at $346,322 \mathrm{~nm}$,
$318 \mathrm{~nm}$ and $328 \mathrm{~nm}$ (Fig. 8) for A1, A2, A3 and A4 samples. The $\mathrm{Ce}^{3+}$ ions substituted into $\mathrm{NiO}$ matrix, due to the varying of the optical properties. This result, absorption peaks edge values decreased with increasing $\mathrm{Ce}^{3+}$ ions concentration. The optical band gap $\left(\mathrm{E}_{\mathrm{g}}\right)$ can be calculated by Tauc relation [24]. The optical band gap was observed at $2.65 \pm 0.1 \mathrm{eV}, 2.8 \pm 0.1 \mathrm{eV}, 2.85 \pm 0.1 \mathrm{eV}$ and $2.9 \pm 0.1 \mathrm{eV}$ (Fig. 9) for A1, A2, A3 and A4 samples. The Blue shift of absorption and the increasing band gap of $\mathrm{Ce}$ doped $\mathrm{NiO}$ nanoparticles are evidence of the quantum confinement effect. The trends of the band gap energy value increased due to the decrease in the crystalline size for Ce doped $\mathrm{NiO} N \mathrm{~N}$. The corresponding effects are also reflected in the $x$-ray powder diffraction (XRD) result due to $\mathrm{Ce}^{3+}$ ion substitution effects.

Figure 10 shows that a PL spectrum of $A 1, A 2, A 3$ and A4 samples with excited wavelength is $320 \mathrm{~nm}$. The pure $\mathrm{NiO}$ nanoparticles $\mathrm{PL}$ emission values are observed at $364 \mathrm{~nm}, 439,481 \mathrm{~nm}$ and $527 \mathrm{~nm}$ respectively. The strong near band edge emission is centered at $364 \mathrm{~nm}$, which is due to the recombination of excitons. The blue emission located at 439 and $481 \mathrm{~nm}$ is attributed to the surface oxygen vacancies of NiO NPs. The green emission bands
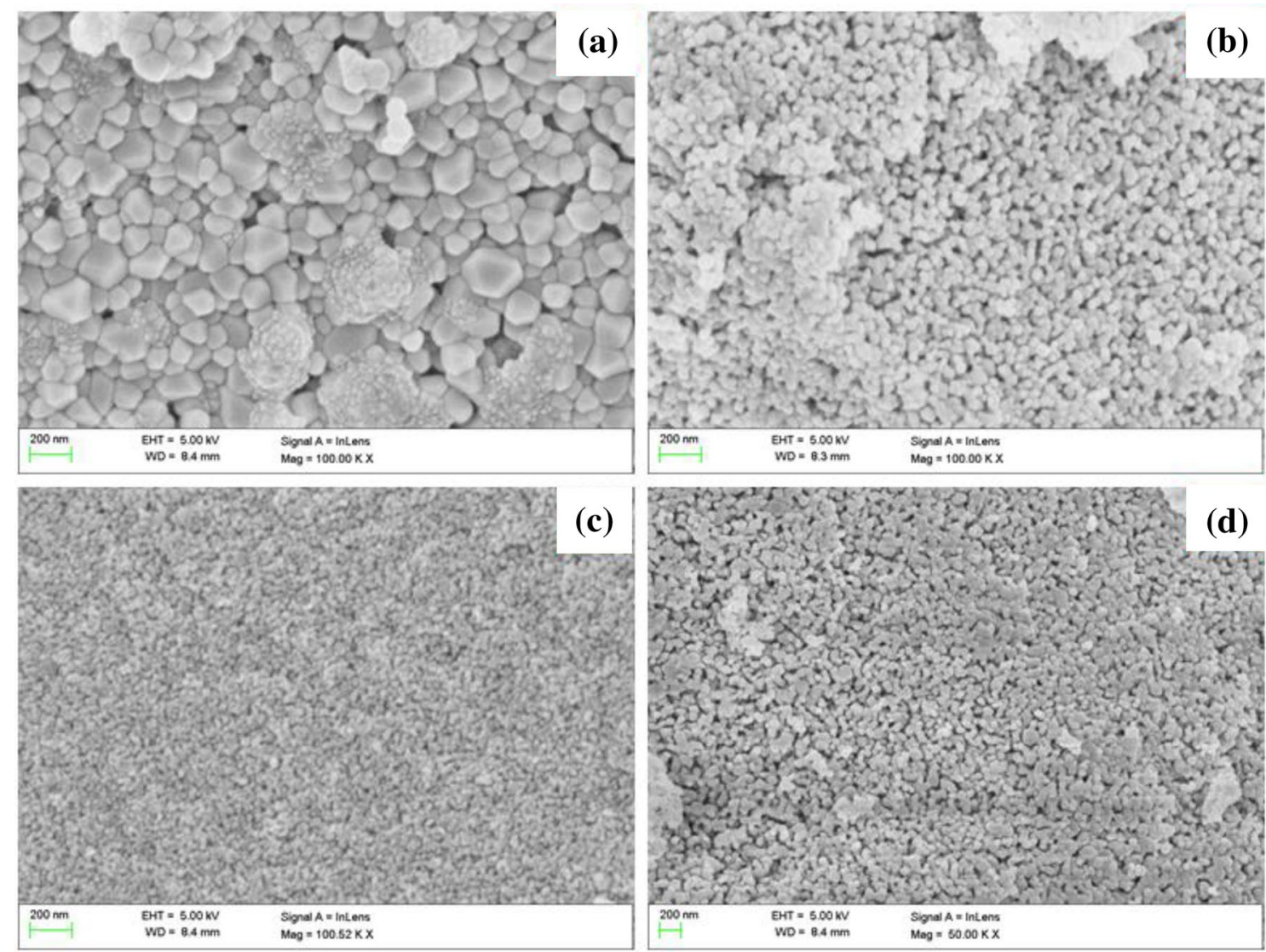

Fig. 4 a-d FESEM images of $\mathrm{Ni}_{1-\mathrm{x}} \mathrm{Ce}_{\mathrm{x}} \mathrm{O}$ NPs for $\mathrm{x}=0.0,0.01,0.02$ and 0.03

SN Applied Sciences

A SPRINGER NATURE journal 

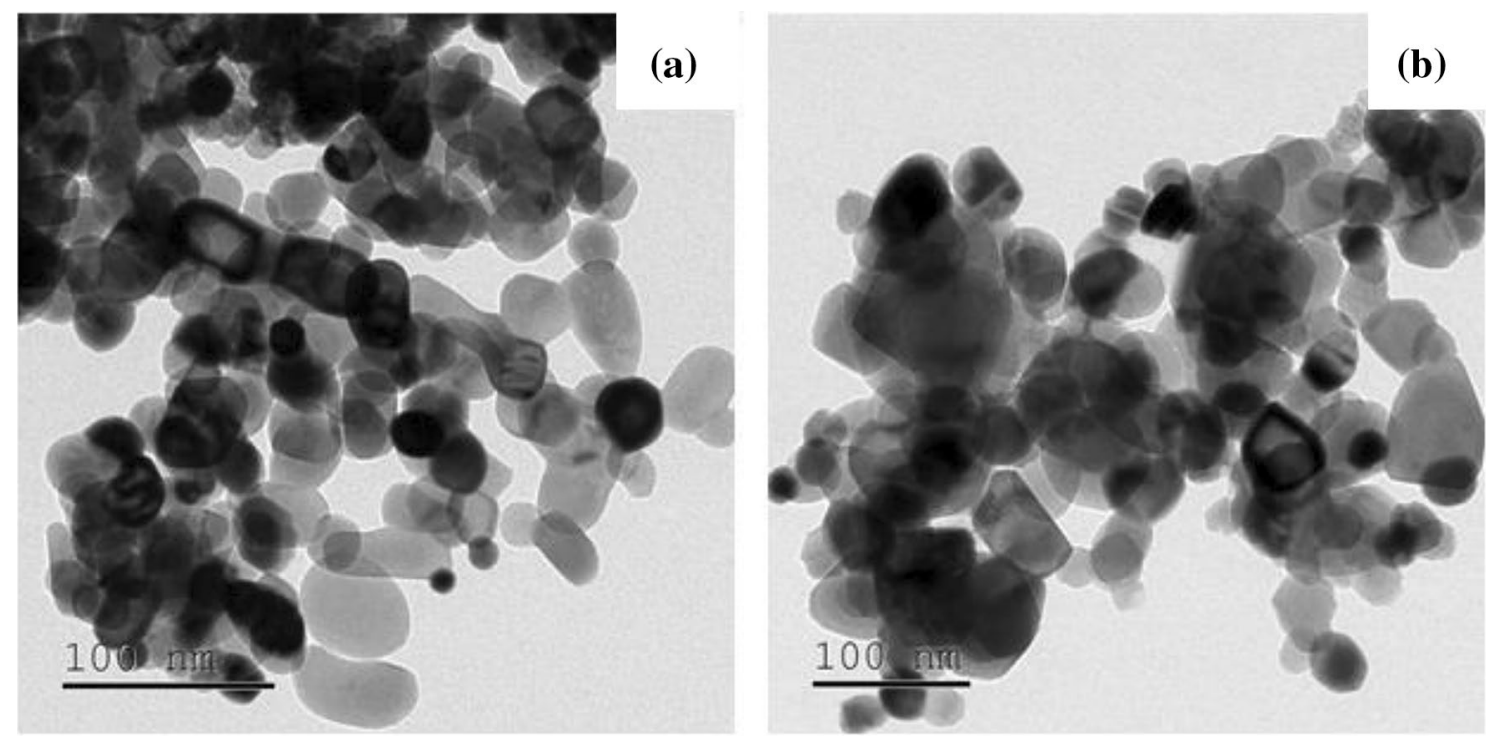

Fig. 5 a, b TEM images of $\mathrm{NiO}$ and $\mathrm{Ni}_{0.097} \mathrm{Ce}_{0.03} \mathrm{O}$ NPs
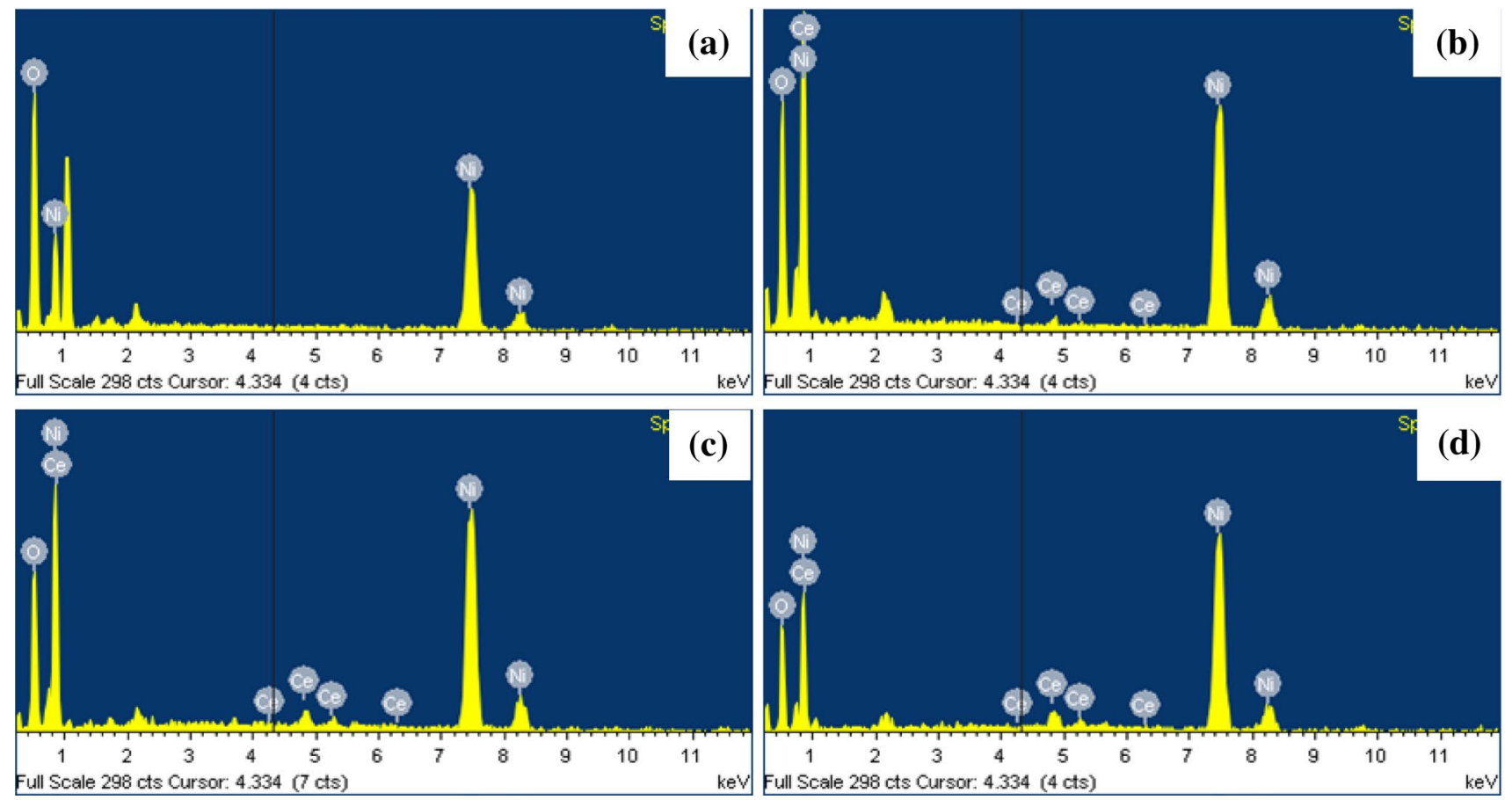

Fig. 6 a-d EDAX spectra of $\mathrm{Ni}_{1-\mathrm{x}} \mathrm{Ce}_{\mathrm{x}} \mathrm{O}$ nanoparticles for $\mathrm{x}=0.0,0.01,0.02$ and 0.03

observed at $527 \mathrm{~nm}$, this is due to the defects originated from the NiO lattice such as cation vacancies, interstitial oxygen trapping, and nickel vacancies produced by charge transfer between $\mathrm{Ni}^{2+}$ and $\mathrm{Ni}^{3+}$ ions $[24,25]$. The intensities of peak decreased with the increase in Ce content. This doping effect produced a large variation inside the $\mathrm{NiO}$ nanoparticles active sites and it formed nickel interstitials
$\left(\mathrm{N}_{\mathrm{i}}\right)$, and oxygen vacancies $\left(\mathrm{V}_{\mathrm{O}}\right)$. This may be due to the predominant of $\mathrm{Ce}^{3+}$ ionic effect [25].

Figure 11 shows the VSM analysis of $A 1$ and $A 3$ samples. The $A 1$ sample exhibits super paramagnetic behavior and $\mathrm{A} 3$ exhibits ferromagnetic behavior at room temperature. The saturation magnetization values (Ms) were observed at 0.002 and $0.004 \mathrm{emu} / \mathrm{g}$ for $\mathrm{NiO}$ and $\mathrm{Ce}$ doped 
Table 2 Elemental composition of $\mathrm{NiO}$ and Ce doped NiO NPs

\begin{tabular}{lllll}
\hline Sample & \multicolumn{3}{l}{ Weight \% } & \\
\cline { 2 - 5 } & $\mathrm{Ni}$ & $\mathrm{O}$ & $\mathrm{Ce}$ & Total \\
\hline $\mathrm{A} 1$ & 55.49 & 44.51 & - & 100 \\
$\mathrm{~A} 2$ & 53.48 & 45.69 & 0.60 & 100 \\
A3 & 51.68 & 47.03 & 1.29 & 100 \\
A4 & 50.07 & 48.34 & 1.67 & 100 \\
\hline
\end{tabular}

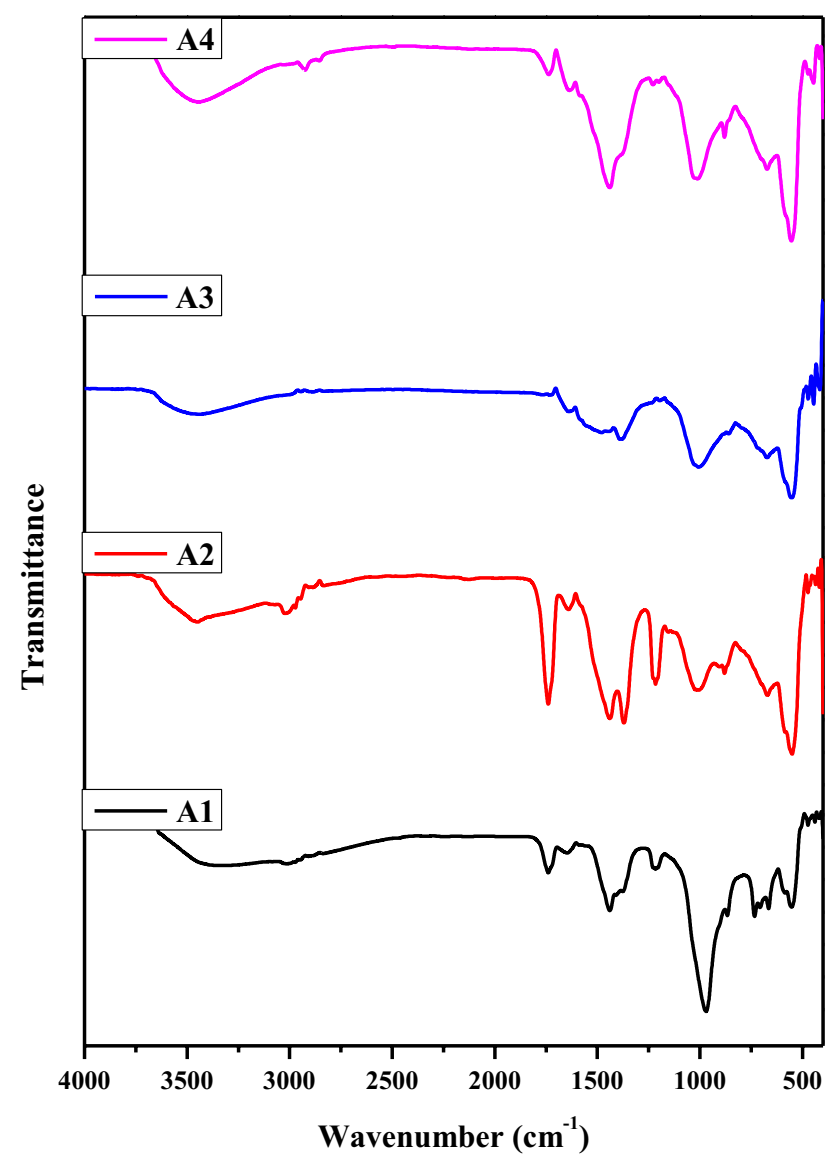

Fig. 7 FT-IR spectra of of $\mathrm{Ni}_{1-\mathrm{x}} \mathrm{Ce}_{\mathrm{x}} \mathrm{O}$ nanoparticles for $\mathrm{x}=0.0,0.01$, 0.02 and 0.03

$\mathrm{NiO}$ nanoparticles. The magnetization values of $\mathrm{A} 3$ are enhanced as compared to $\mathrm{A} 1$ sample due to the $\mathrm{Ce}^{3+}$ ions substitution in $\mathrm{NiO}$ matrix. This magnetic contribution may be the orientation of strong exchange interaction in $\mathrm{s}-\mathrm{f}$ couple with Ce ions.

The antibacterial activities of $\mathrm{A} 1, \mathrm{~A} 2, \mathrm{~A} 3$ and $\mathrm{A} 4$ samples tested against $(\mathrm{G}+)$ bacteria $S$. aureus and S. pneumoniae and (G-) bacteria E. coli, P. aeruginosa, P. vulgaris, K. pneumonia and S.dysenteriae are studied by the well diffusion method as shown in Fig. 12. The A1, A2, A3, A4 and Erythromycin showed the antibacterial activity. The Zone inhibition of bacterial cells may be due to distractions of cell

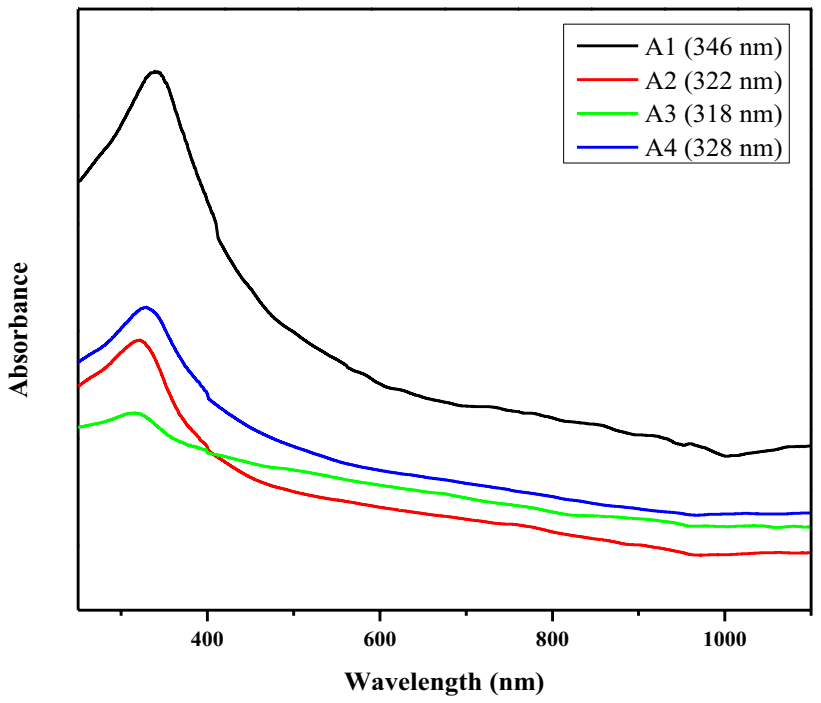

Fig. 8 UV-Vis absorption spectra of of $\mathrm{Ni}_{1-\mathrm{x}} \mathrm{Ce}_{\mathrm{x}} \mathrm{O}$ nanoparticles for $\mathrm{x}=0.0,0.01,0.02$ and 0.03

membrane, is mainly due to the combination of various factors such as $\mathrm{ROS}$ and the release of $\mathrm{Ni}^{2+}$, bacteria losing the viability of cell division, finally bacterial cells are death [26-29]. The schematic diagram of antibacterial mechanism is shown in Fig. 13. The S. aureus, E. coli, K. pneumonia and $S$. dysenteriae bacteria caused serious infections for human system such as breathing problem, dysentery, anemia or kidney failure, wound infections and urinary tract infections [30-33]. However, the synthesized A1, A2, $A 3$ and $A 4$ samples have been used for curing pneumonia, bloodstream infection, kidney failure, wound infection and urinary tract infections.

\section{Conclusions}

In summary, $\mathrm{NiO}$ and $\mathrm{Ce}$ doped $\mathrm{NiO}$ nanoparticles were prepared through chemical method. The XRD pattern revealed that the synthesized nanoparticles exhibited cubic structure. The oxidation states of $\mathrm{Ni}(2 \mathrm{p}) \mathrm{Ce}$ (3d) and $O$ (1s) were identified by $x$-ray photoelectron spectroscopy spectra for NiO NPs. The morphology were identified through FESEM and TEM analysis. The chemical compositions were identified through EDAX analysis. FT-IR spectra explained $\mathrm{Ni}-\mathrm{O}$ stretching vibration observed at $439,435,445$, and $446 \mathrm{~cm}^{-1}$ for respective NiO nanoparticles. The UV-Vis absorption spectra showed the absorption peak edges which are observed at $346,322,318$ and $328 \mathrm{~nm}$ in $\mathrm{A} 1, \mathrm{~A} 2, \mathrm{~A} 3$ and $\mathrm{A} 4 \mathrm{sam}$ ples. The Ce doping of NiO NPs altered the band emission as compared to NiO NPs due to Nickel vacancies, oxygen vacancies and surface defects. The enhanced 

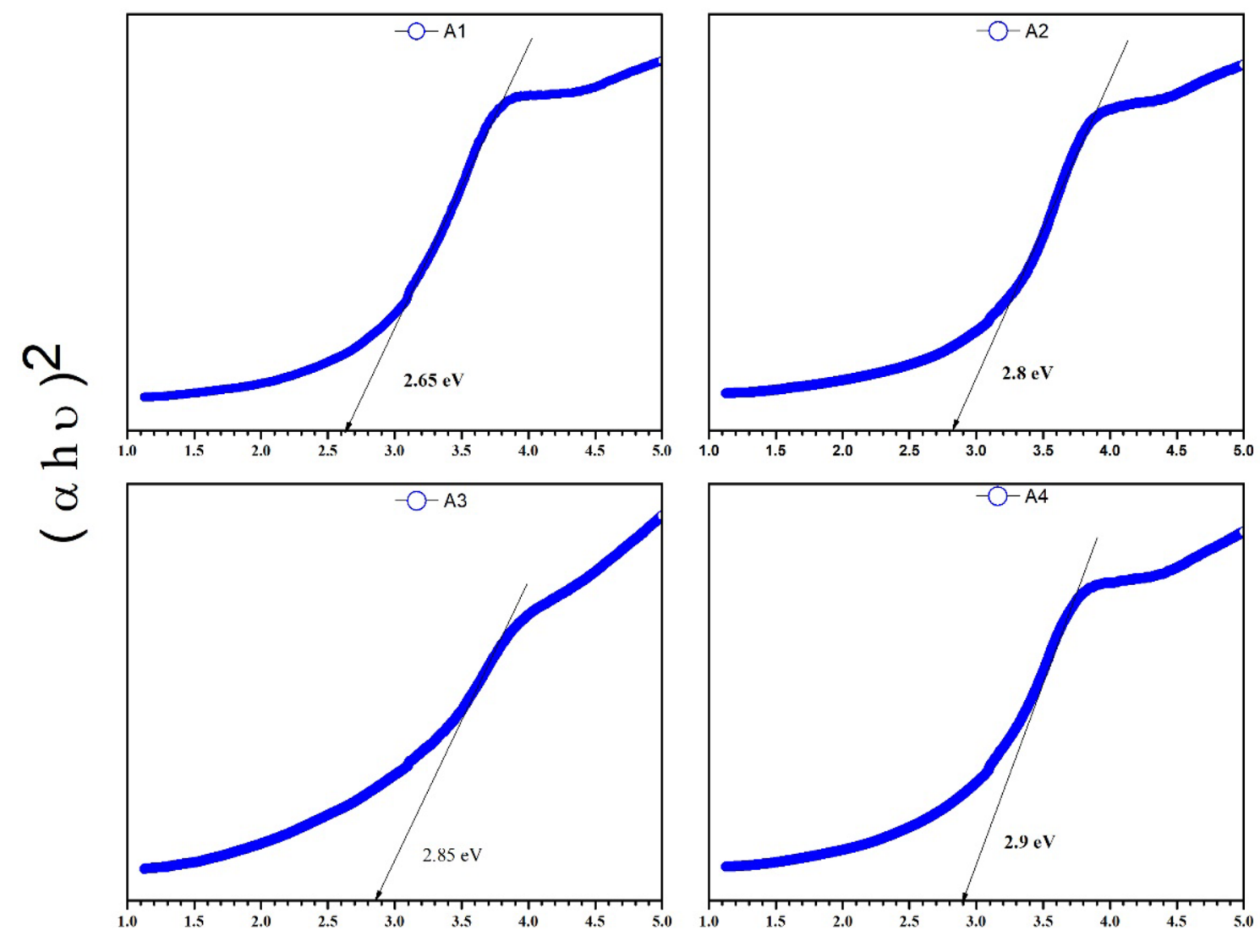

Photon Energy (eV)

Fig. 9 Photon energy values of $\mathrm{Ni}_{1-\mathrm{x}} \mathrm{Ce}_{\mathrm{x}} \mathrm{O}$ nanoparticles for $\mathrm{x}=0.0,0.01,0.02$ and 0.03

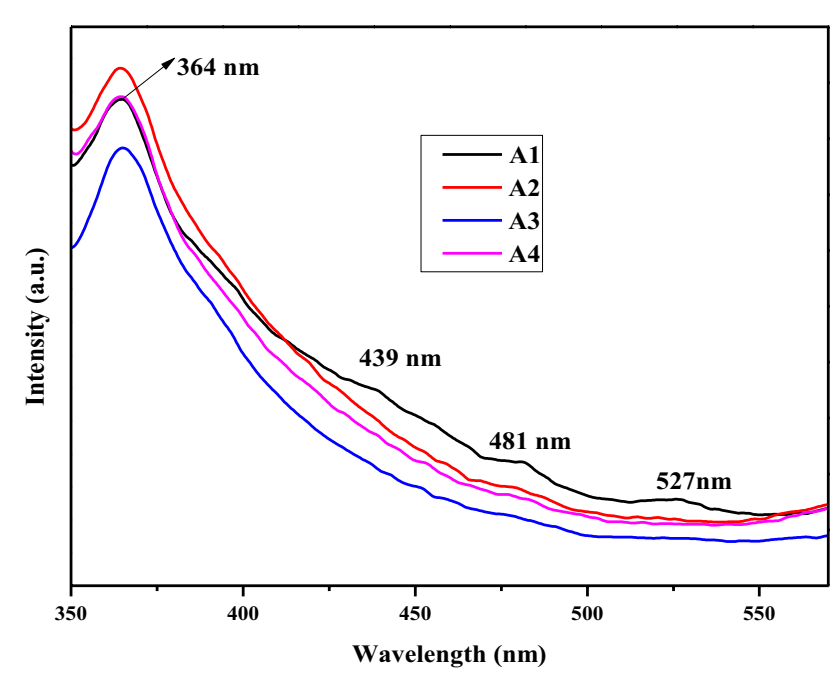

Fig. 10 PL spectra of $\mathrm{Ni}_{1-x} \mathrm{Ce}_{\mathrm{x}} \mathrm{O}$ nanoparticles for $\mathrm{x}=0.0,0.01,0.02$ and 0.03

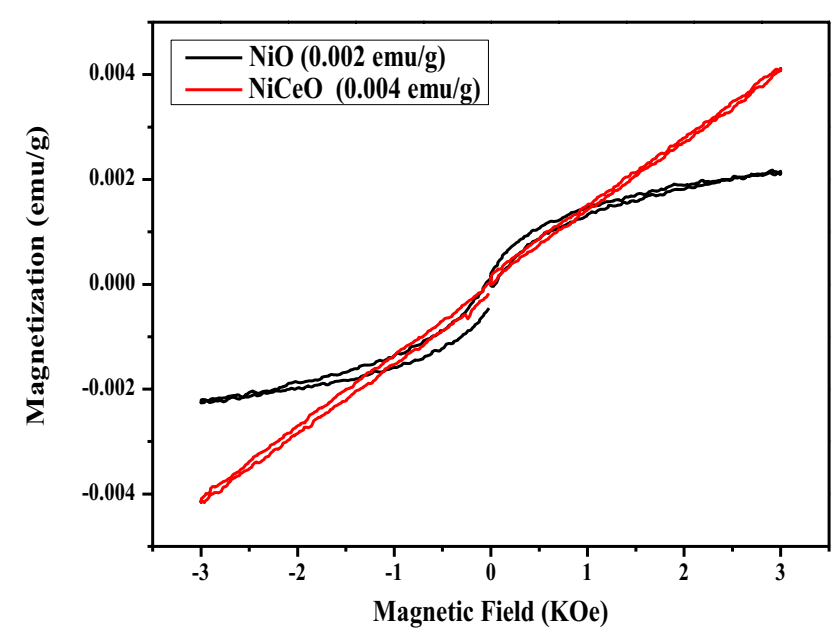

Fig. 11 Hysteresis curve of $\mathrm{NiO}$ and $\mathrm{Ce}$ doped $\mathrm{NiO}$ nanoparticles

magnetization values of $\mathrm{Ce}$ doped $\mathrm{NiO} \mathrm{NPs}$ are more than that of NiO NPs, which was due to $\mathrm{Ce}^{3+}$ ions substitution in $\mathrm{NiO}$ matrix. The $\mathrm{NiO}, \mathrm{Ce}$ doped $\mathrm{NiO}$ NPs and 

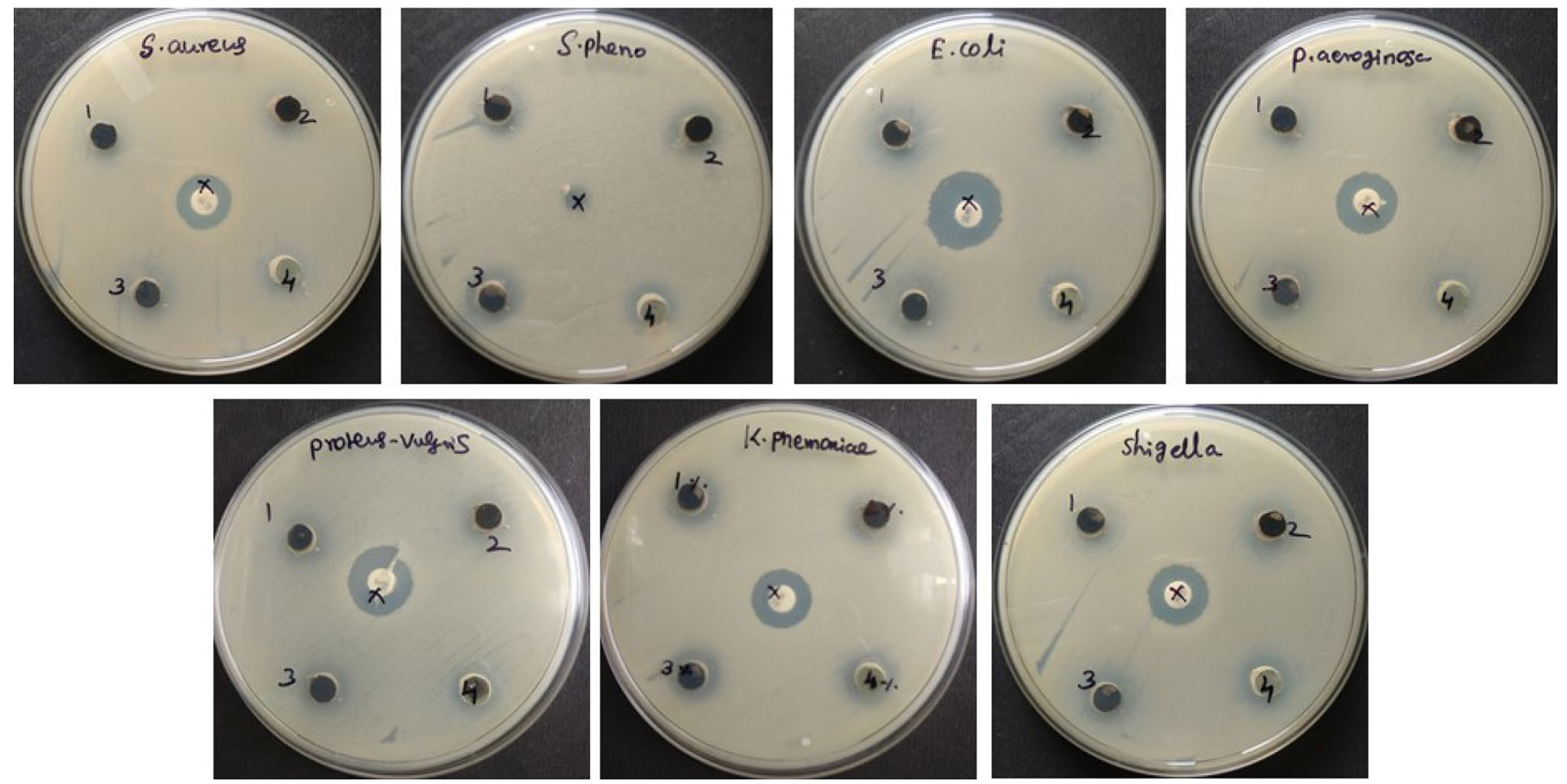

Fig. 12 The progressive antibacterial activity of $\mathrm{Ni}_{1-x} \mathrm{Ce}_{\mathrm{x}} \mathrm{O}$ nanoparticles for $\mathrm{x}=0.0,0.01,0.02$ and 0.03 against Gram-positive (S. aureus and S. pneumoniae) and Gram-negative bacteria (E. coli, P. aeruginosa, P. vulgaris, K. pneumonia and S. dysenteriae)

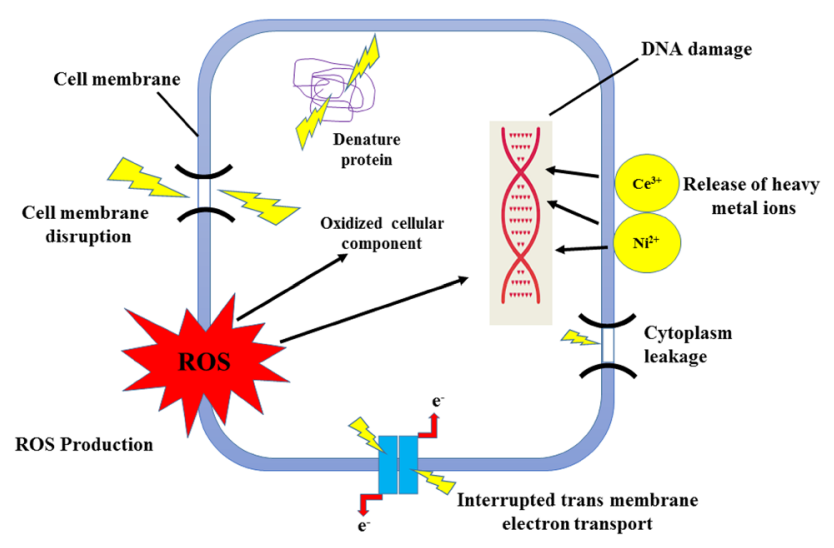

Fig. 13 Antibacterial activity of $\mathrm{Ce}$ doped $\mathrm{NiO}$ nanoparticles against bacterial pathogens

Erythromycin exhibited antibacterial activity. We suggest that synthesized $\mathrm{NiO}$ and $\mathrm{Ce}$ doped $\mathrm{NiO}$ nanoparticles can be used for the treatment of various human diseases such as pneumonia, bloodstream infection, kidney failure, wound infection and urinary tract infections.

Author contributions Mr. MAR carried out the preparation of nanoparticles and executes the physical characterization studies and contributed to the main text of the manuscript. Dr. RRK checked the scientific information and flow of the text to maintain a better readability. Further this research work is not funded by any agency.

\section{Compliance with ethical standards}

Conflict of interest The authors declared that they have no conflict of interest.

\section{References}

1. Rahman MA, Radhakrishnan R, Gopalakrishnan R (2018) Structural, optical, magnetic and antibacterial properties of $\mathrm{Nd}$ doped $\mathrm{NiO}$ nanoparticles prepared by co-precipitation method. J Alloys Compd 742:421-429

2. Du YP, Zhang YW, Sun LD, Yan CH (2008) Efficient energy transfer in monodisperse Eu-doped $\mathrm{ZnO}$ nanocrystals synthesized from metal acetylacetonates in high-boiling solvents. J Phys Chem C 112:12234-12241

3. Flor J, de Lima SAM, Davolos MR (2004) Effect of reaction time on the particle size of $\mathrm{ZnO}$ and $\mathrm{ZnO}$ : Ce obtained by a sol-gel method. Prog Colloid Polym Sci 128:239-243

4. Zeng XY, Yuan JL, Wang ZY, Zhang LD (2007) Nanosheetbased microspheres of $\mathrm{Eu}^{3+}$-doped $\mathrm{ZnO}$ with efficient energy transfer from $\mathrm{ZnO}$ to $\mathrm{Eu}^{3+}$ at room temperature. Adv Mater 19:4510-4514

5. Wang X, Kong XG, Yu Y, Sun YJ, Zhang H (2007) Effect of annealing on upconversion luminescence of $\mathrm{ZnO}: \mathrm{Er}^{3+}$ nanocrystals and high thermal sensitivity. J Phys Chem C 111:15119-15124

6. Walkey C, Das S, Seal S, Erlichman J, Heckman K, Ghibelli L, Traversa E, McGinnis JF, Self WT (2015) Catalytic properties and biomedical applications of cerium oxide nanoparticles. Environ Sci Nano 2(1):33-53

7. Ivanov VK, Shcherbakov AB, Usatenko AV (2009) Structure-sensitive properties and biomedical applications of nanodispersed cerium dioxide. Russ Chem Rev 78(9):855

\section{SN Applied Sciences}


8. Xu C, Qu X (2014) Cerium oxide nanoparticle: a remarkably versatile rare earth nanomaterial for biological applications. NPG Asia Mater 6(3):e90

9. Yang H, Tao Q, Zhang X, Tang A, Ouyang J (2008) Solid-state synthesis and electrochemical property of $\mathrm{SnO} 2 / \mathrm{NiOnanoma-}$ terials. J Alloys Compd 459(1):98-102

10. Bahadur J, Sen D, Mazumder S, Ramanathan S (2008) Effect of heat treatment on pore structure in nano-crystalline $\mathrm{NiO}$ : a small angle neutron scattering study. J Solid State Chem 181(5):1227-1235

11. Hotovy I, Huran J, Spiess L, Hascik S, Rehacek V (1999) Preparation of nickel oxide thin films for gas sensors applications. Sensors Actuators B Chem 57(1):147-152

12. Nathan T, Aziz A, Noor AF, Prabaharan SR (2008) Nanostructured $\mathrm{NiO}$ for electrochemical capacitors: synthesis and electrochemical properties. J Solid State Electrochem 12(7-8):1003-1009

13. Granqvist CG (ed) (1995) Handbook of inorganic electrochromic materials. Elsevier, New York

14. Pankhurst QA, Connolly J, Jones SK, Dobson JJ (2003) Applications of magnetic nanoparticles in biomedicine. J Phys D Appl Phys 36(13):R167

15. Sun C, Lee JS, Zhang M (2008) Magnetic nanoparticles in MR imaging and drug delivery. Adv Drug Deliv Rev 60(11):1252-1265

16. Li QL, Mahendra S, Lyon DY, Brunet L, Liga MV, Li D, Alvarez PJJ (2008) Antimicrobial nanomaterials for water disinfection and microbial control: potential applications and implications. Water Res 42:4591-4602

17. Foster HA, Ditta IB, Varghese S, Steele A (2011) Photocatalytic disinfection using titanium dioxide: spectrum and mechanism of antimicrobial activity. Appl Microbiol Biotechnol 90:1847-1868

18. Wilson WW, Wade MM, Holman SC, Champlin FR (2001) Status of methods for assessing bacterial cell surface charge properties based on zeta potential measurements. J Microbiol Methods 43:153-164

19. Hattori Y, Konishi T, Kaneko K (2002) XAFS and XPS studies on the enhancement of methane adsorption by $\mathrm{NiO}$ dispersed ACF with the relevance to structural change of $\mathrm{NiO}$. Chem Phys Lett 355(1):37-42

20. Salavati-Niasari M, Mir N, Davar F (2010) A novel precursor in preparation and characterization of nickel oxide nanoparticles via thermal decomposition approach. J Alloys Compd 493(1):163-168

21. Zandi S, Kameli P, Salamati H, Ahmadvand H, Hakimi M (2011) Microstructure and optical properties of $\mathrm{ZnO}$ nanoparticles prepared by a simple method. Physica B 406(17):3215-3218

22. Vallée C, Goullet A, Granier A, Van der Lee A, Durand J, Marliere $C$ (2000) Inorganic to organic crossover in thin films deposited from O2/TEOS plasmas. J Non-Cryst Solids 272(2):163-173
23. Meybodi SM, Hosseini SA, Rezaee M, Sadrnezhaad SK, Mohammadyani D (2012) Synthesis of wide band gap nanocrystalline$\mathrm{NiO}$ powder via a sonochemical method. Ultrasonicssonochemistry 19(4):841-845

24. Karthikeyan B, Pandiyarajan T, Hariharan S, Ollakkan MS (2016) Wet chemical synthesis of diameter tuned NiO microrods: microstructural, optical and optical power limiting applications. CrystEngComm 18:601-607

25. Hagfeldt A, Graetzel M (1995) Light-induced redox reactions in nanocrystalline systems. Chem Rev 95(1):49-68

26. Al-Tuwirqi R, Al-Ghamdi AA, Aal NA, Umar A, Mahmoud WE (2011) Facile synthesis and optical properties of $\mathrm{Co}_{3} \mathrm{O}_{4}$ nanostructures by the microwave route. Superlattices Microstruct 49:416-421

27. Kasinathan K, Kennedy J, Elayaperumal M, Henini M, Malik M (2016) Photodegradation of organic pollutants RhB dye using UV simulated sunlight on ceria based $\mathrm{TiO} 2$ nanomaterials for antibacterial applications. Sci Rep 6(1):38064

28. Javid A, Kumar M, Yoon S, Lee JH, Han JG (2017) Size-controlled growth and antibacterial mechanism for $\mathrm{Cu}$ : $\mathrm{C}$ nanocomposite thin films. Phys Chem Chem Phys 19:237-244

29. Tiwari V (2014) Anti-bacterial activity of polyvinyl pyrrolidone capped silver nanoparticles on the carbapenem resistant strain of Acinetobacter baumannii. J Nanomed Nanotechnol 5(06):1

30. Santhoshkumar A, Kavitha HP, Suresh R (2016) Hydrothermal synthesis, characterization and antibacterial activity of $\mathrm{NiO}$ nanoparticles. J Adv Chem Sci 24:230-232

31. Klebsiella pneumoniae in Healthcare Settings. Centers for Disease Control and Prevention. August 27, 12; http://www.cdc. gov/HAl/organisms/klebsiella/klebsiella.html. Accessed 5 June 2015

32. Besser RE, Lett SM, Weber JT, Doyle MP, Barrett TJ, Wells JG, Griffin PM (1993) An outbreak of diarrhea and hemolytic uremic syndrome from Escherichia coli 0157: $\mathrm{H} 7$ in fresh-pressed apple cider. JAMA 269(17):2217-2220

33. Dealler SF, Hawkey PM, Millar MR (1988) Enzymatic degradation of urinary indoxyl sulfate by Providencia stuartii and Klebsiella pneumoniae causes the purple urine bag syndrome. J Clin Microbiol 26(10):2152-2156

Publisher's Note Springer Nature remains neutral with regard to jurisdictional claims in published maps and institutional affiliations. 